\title{
Ambivalence About International Trade in Open- and Closed-ended Survey Responses
}

\section{Arturo Chang, Thomas Ferguson, Jacob Rothschild, and Benjamin I. Page*}

\author{
Working Paper No. 162
}

\section{September $1^{\text {st }}, 2021$}

\begin{abstract}
Spontaneous, open-ended survey responses can sometimes better reveal what is actually on people's minds than small sets of forced-choice, closed questions. Our analysis of closed questions and trade-related open-ended responses to 2016 ANES "likes" and "dislikes" prompts indicate that Americans held considerably more complex, more ambivalent, and - in many cases - more negative views of international trade than has been apparent in studies that focus only on closed-ended responses. This paper suggests that contrast between open- and closed-question data may help explain why the effectiveness of Donald Trump's appeals to trade resentments surprised many observers.
\end{abstract}

https://doi.org/10.36687/inetwp162

JEL codes: C83; F10; F13, F59, F68

Keywords: Free Trade; Public Opinion; international trade; Donald Trump; opinion surveys,

* Arturo Chang is Assistant Professor, Department of Political Science, University of Toronto; Thomas Ferguson is Professor Emeritus at the University of Massachusetts, Boston, Director of Research at the Institute for New Economic Thinking, and Senior Fellow at Better Markets; Jacob Rothschild is Senior Data Scientist, Reality Check; Benjamin I. Page is Gordon S. Fulcher Professor of Decision Making at Northwestern University. 
political economy. 
Closed-ended questions are the bread and butter of survey research, but open-ended questions can be useful for gathering a more nuanced understanding of respondent opinions. Spontaneous, open-ended responses may signal the intensity or salience of opinion and can reveal concerns, ideas, beliefs, priorities, and policy preferences that are actually on people's minds - even if not foreseen by investigators or evoked by closed questions (see Backstrom (1981); Kelly (1983); Craig (1985); Stanga and Sheffield (1987); Smith (1989); Geer (1988, 1991); Zaller and Feldman (1992); Schuman and Presser (1996 [orig. pub. 1981], ch.3); and Vannette and Krosnick (2018)). As part of a broader study of the roots of right-wing populism (Ferguson et al., 2020), we have found that open-ended responses reveal considerably more complexity - and more ambivalence and negativity - in Americans' views of international trade than has been inferred from widely cited closed questions. This paper presents our case for this conclusion.

\section{International Trade in Theory, Public Discourse, and the Polls}

If mainstream economists agree on any one thing, it is that there are "gains from trade." Whenever two well-informed individuals voluntarily exchange goods, services, or money, they say, both parties to a trade are bound to come out better off than they were before. Otherwise, why would they trade? The extension to international trade might seem straightforward. Since Adam Smith and David Ricardo, nearly all mainstream or "neoclassical" economists in Anglo Saxon countries have agreed that two nations as a whole are each made better off by voluntary trade. Each country exports goods that it can make relatively cheaply through comparative advantages in land, labor, or capital; and each country imports what it cannot easily make on its own. Both gain - in a gross, aggregate sense - from trade (Smith 1976 [1776]; Ricardo 1963 [1817].)

But it does not follow that international trade is uniformly and unambiguously good for everyone within a trading country. Many citizens are not voluntary parties to international trades. Those who are not parties can suffer severe harms ("negative externalities"), as might happen to workers in a U.S. factory that closes due to competition from cheap imports. Paul Samuelson - the founder of much of modern trade theory - demonstrated theoretically how trade can affect income distribution. For example, the price of labor 
(i.e., wages) in advanced, capital-rich countries may fall due to international trade with poor countries that have abundant cheap labor. Many advanced-country workers may come out worse off than they would have been without trade (Stolper and Samuelson 1941; Samuelson 1948, 1949 [formalizing an early "Heckscher-Ohlin," multi-factors-ofproduction model]; see also Samuelson 1971.).

As Samuelson shows, this has big consequences for thinking about whether trade is unambiguously "good." Under the key normative principle of modern economics - that only "Pareto improvements" (from which no one loses) should count as improvements in over-all social welfare - a nation's gains from trade constitute unambiguous improvements only if the losers are actually compensated from those gains, so that they come out better off or at least no worse off. But in the real world, large-scale redistribution of gains from trade seldom, if ever, occurs.

As a leading textbook on international economics summarizes the situation: "...when countries [emphasis added] sell goods and services to each other, this exchange is almost always to their mutual advantage.” Yet, “... it is quite possible that international trade may hurt particular groups within nations ... [I]t has become increasingly clear that the real wages of less-skilled workers in the United States have been declining - even though the country as a whole is continuing to grow richer. Many commentators attribute this to growing international trade ..." (Krugman, Obstfeld and Melitz 2015, pp.3-4.) While trade might be assessed as "good" in principle, there is a need to attend to the inequalities that stem from international trade and how voters in turn respond to these complexities.

International trade has probably harmed more Americans than this mild language suggests. As transportation costs have dropped, political barriers (e.g., those isolating communist regimes in China and Russia) have fallen, and a series of free trade agreements have been enacted, the volume of international trade has skyrocketed. Moreover, the income-distributional effects of trade are now greatly magnified by increased mobility of capital as well as goods across international borders. It is now possible to send billions of dollars abroad with a few clicks on a computer, or to move whole factories abroad to low-wage countries. And cheap telephonic and web communication has rendered workers in most service industries, as well as in 
manufacturing and agriculture, vulnerable to low-wage competition, especially as artificial intelligence and applications of automation to existing industrial processes ramify through the economy.

As a result, since the early 1970s, as imports of goods and services from lower-wage countries have surged, jobs have been displaced, the real wages of many or most American workers have stagnated or fallen, factories have closed, and mortality rates have risen (Taylor and Omer 2018; Case and Deaton 2017.) In places like the Midwestern "rust belt" and in many rural areas, whole towns have been devastated (Monnat and Brown, 2017). A great deal of evidence directly implicates international trade and capital movements - especially, in recent years, trade with China (Scott 2011; Scott and Mokhiber 2020; Autor et al. 2016, 2017.) Further, recent studies of rural political consciousness point to the importance of attending to the idiosyncrasies of these constituencies (Cramer 2016).

It would not be surprising, then, if many Americans held negative, conflicted, or complex views about trade that in turn (as some of the above-cited aggregate evidence indicates) influenced their votes in the 2016 presidential election. If so, can researchers obtain an accurate picture of such individual-level opinions about trade through closed- and/or open-ended survey questions? In this paper we argue that opinions about trade involve important ambiguities and ambivalences that are sometimes missed by closed-ended survey questions, especially when surveys include only a few simplistic, binary, "favor/oppose" items. Open-ended questions can help establish that many people are not simply either "for" or "against" free trade; they care about specific conditions, restrictions, and compensations related to trade. Further, people rarely employ technical, elite-approved language to voice their concerns, but use everyday language - often referring to matters important in their own lives, such as jobs and wages.

Public discourse. The reality of mixed effects from trade has become so obvious that few experts, pundits, or politicians now utter the platitudes that once pervaded public discourse: that "we all benefit from trade," "free trade is good for everyone," and the like. Yet - despite occasional dissenting voices - pro-trade sentiments continue to dominate mainstream U.S. public discourse under different packaging. Until very recently nearly 
all prominent economists, media commentators, and (until Trump) national figures in both major political parties embraced free trade agreements, offering little or no compensation for those who lose out. From 1974 until the early 2000s - when they were discontinued - Chicago Council on Global Affairs (formerly Chicago Council on Foreign Relations) surveys of "foreign policy leaders" (public officials, interest group leaders, media commentators, and the like) regularly showed that large majorities of elites favored free trade agreements and few were concerned about job losses (Rielly 1975 et seq.; Bouton 2004, 2008, 2010.) Other studies of American elites found the same pattern Ferguson, 1986). Even late in 2016, during the Trump campaign onslaught against trade agreements, President Barack Obama extolled the benefits of free trade (Economist 2016). This consensus regularly found its way into the mass media and public discourse.

In recent years, the leading intellectual cheerleaders for free trade have emphasized its clear benefits (cheap consumer goods, a higher GDP) while downplaying - but not denying the existence of - its costs. Douglas Irwin (2015), for example, acknowledges that some sort of policy to help displaced workers is needed in order to avoid political opposition to free trade. But then he devotes barely two pages in a book of over 300 pages to how compensation might be provided: through temporary and skimpy "wage insurance" (Irwin 2015, 146, 153-54). Similarly, Thomas Friedman's (2007) popular paean to the "flat world" of economic globalization is crammed with exciting details about trade efficiencies and gains to the United States as a whole, but skimpy about the plight of those "in certain fields" whose wages may be "dampened" in a "transition phase" of uncertain duration (p. 265.). Friedman's solution is for workers to adapt and learn new skills and for policy makers to upgrade our education system. The brieflymentioned idea of compensating trade losers through "cushions" like wage insurance is easily lost in his 635-page book (p. 391-94). Even Dani Rodrik, a trenchant critic of the existing rules of international trade, pays little attention to the possibility of spreading gains from trade so that everyone benefits. He briefly notes European efforts to do so through generous safety nets and social insurance programs but declares that it is "too late" for the United States to do the same (Rodrilk 2018, 203-06).

Trade in the polls. Given the pro-trade tilt in what Americans have seen and heard in the 
media - and the understandable tendency of people to appreciate the availability of cheap imported goods at Walmart - it is not surprising that simple closed-ended poll questions about "free trade" or "free trade agreements" (including specific agreements like NAFTA and the TPP) have generally shown a high level of support (see, for example, Pew 2015; Smeltz et al. 2019, pp. 22-24; Saad 2019). Most polling organizations have emphasized large majority support for free trade. This has become conventional wisdom. Any complexity, ambivalence, or negativity in Americans' attitudes about international trade has generally been downplayed or ignored (but see Saad 2019).

The oversimplified conventional wisdom about trade attitudes probably arises partly from relying on closed survey questions that leave little room for ambivalence or complexity. To be sure, however, such an effect may not be inherent in closed-question methodology itself. Much depends upon various actors' choices concerning how many, and precisely what sorts of, closed questions are designed and fielded; how they are interpreted; and how well they are publicized. Given a large enough number of well-designed closed questions, it may be possible to piece together a picture that includes considerable complexity and nuance.

This might be done, for example, by searching through the online data archive of the Chicago Council on Global Affairs at thechicagocouncil.org. Over the years, the Chicago Council has documented that large majorities of Americans believe that many or most specific U.S. trading partners practice "unfair" rather than fair trade; that large majorities favor environmental and workplace restrictions on goods imported from abroad (see Bouton and Page 2002, Bouton 2004, 2006); and, most importantly, that concerns about Americans' jobs are highly relevant to attitudes about trade. In multiple surveys since 1978 , in response to a battery of questions about possible U.S. foreign policy goals, the Chicago Council has regularly found large majorities of Americans saying that "protecting the jobs of American workers" should be a very important goal. Frequently, more Americans have attributed high importance to job protection than have said the same about any of a dozen or so other possible goals, including national security matters bearing on war and peace (Rielly 1975 et seq.; Bouton 2002, 2004, 2008, 2010; Smeltz et al. 2016; Smeltz et al. 2019). 
Pew (2015) has found that Americans strongly tend to attribute job losses to free trade, and that fewer than half (especially among lower-income people) believe that trade has benefitted them personally. In general, when closed questions about tariffs or trade explicitly bring up job protection, expressed views about pure free trade become decidedly more negative. Support for tariffs or other protective measures rises. In the earliest decades of Chicago Council surveys, for example, a closed question pitted "the cost of goods... go[ing]down for everyone" if all tariffs and restrictions on imported goods were eliminated by all countries, against such tariffs being "necessary" to "protect certain manufacturing jobs in certain industries from the competition of less expensive imports." The Council regularly found large pluralities saying they sympathized more with those who think such tariffs are necessary than with those who want to eliminate tariffs. But this question has rarely if ever been repeated by the Council or others since 1998.

Instead, for a while an unusual three-alternative closed question in Chicago Council surveys focused on the idea of free trade with compensation or help for losers and has shown strong support for compensation. In six Council surveys between 2004 and 2017, large pluralities - and in the two most recent surveys, absolute majorities - of Americans have said they favor "lowering trade barriers, such as tariffs, provided that [emphasis added] the government has programs to help workers who lose their jobs." About one third of respondents have rejected even this, flatly saying they "oppose agreements to lower trade barriers." Only a small minority - ranging from 10-15\% - have said they favor trade agreements but oppose programs to help workers (data archive search at thechicagocouncil.org). These data seem quite illuminating but issues related to methods or magnitudes of compensation have not been explored or discussed by much by the Council or others.

Again, with a sufficient number of well-designed closed questions, it might be possible to fill in a reasonably complex and differentiated picture of public attitudes about trade. Most polls and surveys that touch upon trade, however, make room for only one or two questions about the topic. Most ask rather simple questions, without complex response alternatives or time-consuming explanatory prologues. Instead, closed-ended questions 
tend to nudge respondents to endorse "free trade" in the abstract, not mentioning considerations of trade fairness, environmental or workplace restrictions, or jobs-related issues. That may have created a misleading picture of popular attitudes, which in turn may have contributed to many observers' surprise at the traction that then-presidentialcandidate Donald Trump gained in 2016 from his bashing of free trade agreements.

Even the American National Election Studies (ANES) - generally considered the goldstandard source of data for scholars of individual political behavior in the U.S. - appears to have fallen prey to this tendency. In the comprehensive 2016 ANES election survey, only three trade-related closed questions were asked, a number that could not possibly illuminate the full complexity or ambivalence of Americans' attitudes about international trade. Moreover, two of those three items tended to nudge respondents toward responses that "trade" or "free trade," is "good" for the U.S. as a whole, without offering response alternatives or contextual information concerning job protection, compensation of losers from trade, trade fairness, or workplace or environmental restrictions on imports.

The wordings of the 2016 ANES closed trade questions and the weighted marginal frequencies of responses are given in Table 1. Looking at those response frequencies, analysts might be puzzled by the apparent contradiction between the large, $62 \%$ majority that favored placing unspecified "new limits" on imports, and the substantial plurality (38\% to $21 \%$ ) saying that they favor "making free trade agreements" with other countries (what sort of agreements? with what conditions or restrictions, if any?). The "new limits" responses also seem to conflict with the even larger plurality (46\% to 20\%) saying that increasing amounts of trade have been "good" (how good?) "for the United States" (as a whole? for all citizens?). Yet such responses might well be logically consistent with each other (see Page and Shapiro 1992, pp.383-86). The large numbers of respondents saying "neither good nor bad," or "neither favor nor oppose," hint at greater complexity and differentiation of opinion than the closed questions can accommodate. Additional data are needed to find out. 
Table 1

Response Frequencies to Closed Questions on Trade (ANES 2016)

\begin{tabular}{llc}
\hline Question & Response & Percent \\
\hline $\begin{array}{l}\text { Have increasing amounts of trade with } \\
\text { other countries been good for the }\end{array}$ & Good & $45.5 \%$ \\
$\begin{array}{l}\text { United States, bad for the United } \\
\text { States, or neither good nor bad? }\end{array}$ & Bad & $34.4 \%$ \\
& & $20.0 \%$ \\
$\begin{array}{l}\text { Do you favor or oppose placing new } \\
\text { limits on imports? }\end{array}$ & Favor & \\
& Oppose & $62.4 \%$ \\
$\begin{array}{l}\text { Do you favor, oppose, or neither favor } \\
\text { nor oppose the U.S. } \text { making free trade }\end{array}$ & Favor & $37.6 \%$ \\
$\begin{array}{l}\text { agreements with other countries? } \\
\text { (collapsed from seven-point scale) }\end{array}$ & Oppose & $37.9 \%$ \\
\hline $\begin{array}{l}\text { Note: Ns }=3595 \text { (Increasing trade), 2571 (Limit imports), 3595 (Free trade agreements). } \\
\text { Frequencies are calculated using ANES survey weights. }\end{array}$ & $41.1 \%$ \\
\end{tabular}


Anyone who relied solely upon these ANES closed questions, then, could be confused or misled about Americans' trade attitudes. One who analyzed 2016 voting behavior using ANES data could easily miss the importance of trade-related issues in the rise and triumph of Donald Trump (see Ferguson et al. 2020). Fortunately, the ANES also included several open-ended questions that can help to illuminate more of the complexities, ambiguities, and negativities in Americans' trade attitudes.

\section{The Open-ended ANES Data}

Every four years since 1952 the American National Election Studies (ANES) have asked eight open-ended questions concerning what, if anything, might make respondents "want to vote for" (or, in separate questions, "want to vote against") each major presidential candidate, and what they "like" or "dislike" about each of the major parties. (We will follow the usual convention of labeling both sets of questions "likes" and "dislikes.") The precise wording has varied slightly over the years. Multiple responses are encouraged by repeating a probe, standardized since 1968 as "anything else?"1 Personal interviewers have recorded the responses verbatim as best they can. Since 2012 a subset of online respondents has typed their own answers. Starting with the 2008 study, machine-readable text has been entered into spreadsheets that are available to scholars (Berent, Krosnick, and Lupia 2015; Lupia 2018).

Until recently, responses to these open-ended questions were easily transformed into quantitative data through an official ANES coding scheme that assigned each response to a category. This made it possible to do counts of response frequencies and to calculate various individual- and aggregate-level variables. Many scholars have used these data generally relying upon the official coding scheme but combining its specific codes into broader categories of theoretical interest - in order to analyze such topics as the “components of electoral decisions" (Stokes et al. 1958, (Campbell et al. 1980 [1960],

\footnotetext{
${ }^{1}$ Current wording: "Is there anything in particular about [Candidate 1] that might make you want to vote for him/her? What is that?" This is followed by “...anything...that might make you want to vote against [Candidate 1]?" Then the same two questions about Candidate 2. Next, "Is there anything in particular that you like about [Party 1]?," followed by “...anything... that you don't like about [Party 1]?, ”and the same two questions about Party 2. After an initial response to each of the eight questions, the interviewer probes by asking "Is there anything else...?," until the respondent says no.
} 
Stokes 1966); short-term deviations from the "normal vote" (Campbell, Converse, Miller, and Stokes 1966); issue saliency (Kessel 1968); the increased clarity of party perceptions (RePass 1971); the importance of New Deal social welfare issues in voters' minds (Kelley 1983); ideological thinking (Knight 1985); spontaneous mentions of nuclear threat (Schuman, Ludwig, and Krosnick 1986); issue salience and survey methodology (Geer 1988; 1991); and declining partisan identification and voter turnout (Wattenberg 1998, 2002). Only a few scholars have done the painstaking work of reading and recoding the original texts of responses themselves (e.g., Kessel 1968; RePass 1971; Schuman, Ludwig, and Krosnick 1986).

Recently, however, it has become clear that the very detailed official ANES coding scheme (with nearly 600 distinct possible codes) was unreliable. Different coders assigned identical responses to different categories. A special task force led by Arthur Lupia, Jon Krosnick, and Matthew Berent also discovered that coding instructions were often vague or undocumented; coding categories varied from year to year and were not developed in a systematic fashion; and particular codes were used with altered definitions from one study to the next. Not surprisingly, coders actually used rather few of the 600 available coding categories with any frequency. Just ten codes accounted for nearly one third of all coded responses, and (in one survey) $35 \%$ of the available codes were not used at all (Berent, Krosnick and Lupia 2015).

Based on the 2008 open-ended responses, the task force devised, tested, and recommended a much more concise, 38-category scheme (Berent et al. 2015, p. 19). As of the 2016 election study, however, neither that scheme nor any alternative had been implemented by ANES. Beginning with the 2008 survey, no pre-coded "likes" and "dislikes" data have been provided to scholars. Those who want to analyze the openended data have been left on their own to deal with the raw texts of recorded responses.

Coping with raw-text responses. These data are less susceptible than many other types of texts to automated coding and analysis using unsupervised learning models (e.g., Roberts et al. 2014; but see Rothschild et al. 2018), or supervised learning models (which can be particularly helpful for implementing scholars' a priori theoretical schemes: e.g., Ramage et al. 2009). Open-ended survey responses are very different from such carefully 
composed texts as (say) government documents, party platforms, or candidates' speeches. They display the full richness of everyday speech. They are very messy in terms of spelling, sentence structure, and language use. Moreover, the particular uses of language and the particular kinds of linguistic messiness often vary idiosyncratically among individual respondents.

In the 2016 ANES "likes" and "dislikes" data, for example, allusions to international trade and globalization were fairly common. But few respondents employed the precise language of economic theory, and the terms they used differed considerably from person to person. Very few respondents used the words "trade" or "finance" to explain their support of Donald Trump in relation to the economy, even when accounting for misspellings (such as "finense," "finence," or "traid"). Many more alluded to economic stagnation and negative impacts of trade by references to Trump as a "business tycoon," "aggressive" on jobs, having business "sense" or "confidence," and being interested in "fixing" the economy "back to normal." Only careful reading by human coders is likely to detect subtle connections to trade.

The open-ended responses (especially those written by respondents themselves online see Schmidt et al. 2020) include many misspellings, sentence fragments, and ellipses. Automated spelling-correction methods may seem promising, but they rely on predefined dictionaries and word similarities that cannot always ensure the correct contextual rendering of words such as "traid," "finense," "Begazi" [Benghazi] or "foren" [foreign]. For our own work - especially word counts - we concluded that we had better correct spelling errors ourselves.

A further problem with these data is inherent in any effort to go beyond word counts and count the frequencies of particular kinds of comments or concepts. What, exactly, is a "single" comment or concept? Respondents may mention several distinct matters in a single sentence. Multiple responses to a given open-ended question tend to run together in the raw data, sometimes - but not always - demarcated by a forward slash (“/”) or other indication of an intervening "anything else?" probe. As the ANES task force pointed out, an essential first step toward many types of systematic analysis of the open-ended comments is to delimit the responses into separate, distinct "chunks," which we would label the "smallest 
meaningful evaluative elements." This is not a trivial task, especially given fragmentary sentences, lack of grammatical structure, and overlapping meanings. Carefully instructed human coders can do it with fairly high reliability. Using 2008 ANES data, Berent, Krosnick, and Lupia (2015) found response-level inter-coder agreement on "chunking" that ranged from 76 to $85 \%$ for "likes" and "dislikes" questions on McCain, and from 82 to $91 \%$ for questions on Obama. But chunking involves very labor-intensive work and thus proves a difficult method to implement more broadly.

Our first step in using the 2016 open-ended data was to "chunk" each response into its smallest meaningful evaluative elements, at the same time correcting spelling errors. (For a few examples - selected partly to illustrate how extreme the spelling errors can be in the raw data, particularly when online respondents typed in haste - see the Appendix.) This took a team of four research assistants about 15 hours per week each over the course of four weeks, for a total of 240 hours plus supervision time, as pairs of them independently chunked randomized half-sets of responses to each of the eight open-ended questions. Our effort, like the ANES task force's chunking of the 2008 open-ended responses, has been generally successful. But it would be very helpful if in the future the ANES could make available an official "chunked" and spelling-corrected data set as well as the raw data, so that scholars can avoid duplicating this preliminary menial task. In addition to performing simple word counts on the chunked and spelling-corrected data, we have been able to explore the prevalence of concepts related to international trade, imports, outsourcing, economic globalization, and the like, by reading the responses carefully and doing our own substantive classifying and coding.

\section{Open-ended Negativity and Ambivalence about Trade}

Most ANES respondents make a reply to at least one of the open-ended "likes" or "dislikes" questions they are asked. In 2016, only about 5\% had nothing at all to say to any of the eight questions - a figure in line with past benchmarks going back to the 1950s. As others have noted, since the 1980s many more respondents have typically mentioned considerations about candidates than about parties (Wattenberg 1998, 2002; Geer 1988, 1991). In 2016, 94\% said something about one or both candidates - Donald 
Trump and Hillary Clinton - while only $41 \%$ expressed a like or dislike about the Republican or Democratic Party.

At the same time, the very general nature of the "likes" and "dislikes" questions together with the many types of personal characteristics, issue standing, and past experiences that may be relevant to voting choices - ensures that no single policy area like international trade is likely to be mentioned very often. Most common are mentions of candidates' personal characteristics or behavior. In open-ended comments about Clinton in 2016, for example, one topic stood out for spontaneous mention: her alleged “corruption." Fully $17 \%$ of all respondents offering any comment on Clinton (or 10\% of the total respondent pool) mentioned this term. Here there was little disjunction between explicit term and broader concept: most respondents employed the term "corrupt" itself. This may reflect Trump's frequent references to "crooked Hillary" as "the most corrupt candidate in history" when alluding to her Wall Street speaking fees, her use of a private email server as Secretary of State, and questionable practices of the Clinton Foundation. The importance of the "corruption" issue does not come out nearly as clearly in any ANES closed-ended question.

In evaluating Donald Trump, mentions of strong leadership or plain-spoken style were quite common, expressed in a variety of terms and from a variety of perspectives. About $12 \%$ of all those offering comments about Trump praised his "power," "action," "straight-shooter" character, or "brutal" honesty. Many respondents expected that Trump would be more active in keeping the country "safe" and in "saying what the [public] is scared to say." In both cases, open-ended questions demonstrate the value of "common language" responses on political candidates, as well as the framing power Trump's rhetoric had on voter opinions. We believe this vernacular analysis extends to opinion on trade, through which one can analyze the ambiguities of trade opinions beyond a "good" versus "bad" dichotomy.

Trade-related responses. In this context, spontaneous, open-ended mentions of issues related to international trade, globalization, plant relocation, and imports were rather common - more common, and more important, than appears to be the case in most scholarly analyses of 2016 voting (e.g., Sides et al. 2018).On these issues the gap 
between common speech and elite discourse was unusually wide, so that neither closed questions nor simple word counts of open-ended responses could give an accurate picture of Americans' thinking. Only occasionally did explicit comments about "free trade" crop up in the interviews: perhaps only 25 mentions in the entire data set. But this is quite misleading as a guide to the true extent of public concern. A variety of other terms and expressions related to free trade were fairly common, mostly as either admiring comments about Trump or critical remarks about Clinton.

For example, an unusual pro-Clinton comment at the end of a string of other issues: "And, her recent flip flop on no longer agreeing with the TPP” (respondent \#301906). Or, more typically, a Clinton dislike: "Flipflops on the Trans-Pacific Partnership" (403571). Reasons to want to vote for Trump: "He wants to try to better the economy and bring some work back to us" (302851). Or "...he is tough on deals with foreign countries..." (300437). An unusual Trump dislike: "He sends his business overseas, yet he claims he wants to strengthen the U.S. economy with more jobs and production. He's the prime offender of sending things overseas" (302239). Another: "I heard he was bringing in workers from other countries at a lower wage instead of hiring Americans" (300085). No simple word counts are likely to capture the trade-related aspects of various labels for the TPP or NAFTA, let alone the importance of trade in engendering comments like "bring some work back to us," or "deals" with foreign countries, or "bringing in [foreign] workers." Based on our coding, we estimate that $5 \%$ of all respondents, across all the candidate and party questions, alluded to free trade, globalization, or closely related themes. For spontaneous remarks with no prompting - given the great number of other possible types of responses - this strikes us as a significant figure. For a respondent to bring up international trade in that context indicates a high degree of salience or intensity. ${ }^{2}$

Demographically, those who gave trade-related open-ended responses tended to be a little more often male than the full set of ANES respondents (55\% to 48\%); substantially less often Democrats (18\% to 37\%); and somewhat more often Trump voters (59\% to $47 \%)$. Contrary to the usual expectation that the highly educated and more affluent tend to offer more open-ended responses, however, the trade-related open-ended responders

\footnotetext{
${ }^{2}$ Broad mentions of economic concerns were the most common of any general policy topic, appearing among a further $15 \%$ of respondents across the entire data set.
} 
did not differ significantly in education level, and their median income category $(\$ 50$ 55,000 per year) was actually a bit lower than that of the total set of ANES respondents (\$55-60,000.) These income and education findings may reflect the fact that lowerincome Americans tended to feel stronger resentments about trade (which did in fact impact them more negatively), and therefore spoke up about it more often than they would about other matters.

The distribution of trade-related responses across the eight different open-ended questions is quite revealing of negativity about international trade and free trade agreements among a substantial set of Americans with strong enough feelings to bring the topic up spontaneously. And it makes clear that concerns about trade significantly helped Trump and hurt Clinton. As Table 2 shows, fully 6\% of all responses to the Trump "like" question, but only $1 \%$ of Trump dislikes, concerned trade. With Clinton the opposite was true: only a single response $(0.007 \%)$ of all Clinton "likes" concerned trade, whereas $2 \%$ of Clinton "dislikes" did so.

Table 2

Frequencies of Open-Ended Trade-related Comments

\begin{tabular}{|l|l|l|}
\hline Question & Out of Total Respondents & Out of Total Responses \\
\hline Clinton Likes & $0.3 \%$ & $0.007 \%$ \\
\hline Clinton Dislikes & $1 \%$ & $2 \%$ \\
\hline Trump Likes & $2.4 \%$ & $6 \%$ \\
\hline Trump Dislikes & $1.1 \%$ & $1 \%$ \\
\hline Dem Party Likes & $.2 \%$ & $.4 \%$ \\
\hline Dem Party Dislikes & $.1 \%$ & $.02 \%$ \\
\hline Rep Party Likes & $.01 \%$ & $.015 \%$ \\
\hline Rep Party Dislikes & $.01 \%$ & $.02 \%$ \\
\hline
\end{tabular}

Note: "Respondent" percentages are based on the total number of respondents who replied to each of the eight open-ended questions. "Response" percentages are based on the total number of responses to each question - multiple responses are allowed. 
Table 2 also makes clear that very few respondents saw any reason to differentiate the two political parties - to like or dislike one of them over the other - in terms of international trade. After all, until Trump was elected president and took command of the Republican Party, the leading figures in both major parties had almost universally backed free trade, both rhetorically and in supporting trade agreements like NAFTA and the WTO.

The flavor of pro-Trump and anti-Clinton trade-related comments can be conveyed by a few examples. Pro-Trump: “Also like jobs, bring jobs back to America...." (300983); "He's going to bring jobs back to the U.S." (301018); "His views on ... exported goods...." (302675); "I think he would make good trade deals...." (300188); "I agree with building a wall on our southern border and let the Mexicans pay for it through international trade deals. Bring jobs back to America.” (300603); [after some negatives] “...but I'm still going to vote for him....He promises jobs and bringing jobs back to the country, and more honest from China, it's got to be stopped." (300994); Anti-Clinton trade-related comments include, for example, "The biggest thing is she's a globalist, a criminal and a liar.” (301227); “Took my job away from me....” (300375).

Connections among responses. Our analyses of individual respondents' answers to both open and closed ANES questions brings to light a striking ambivalence in attitudes about trade that has often escaped notice. As we mentioned above, the substantial frequency of "neither" [good nor bad, favor nor oppose] responses to closed ANES questions (see Table 1) hints at widespread complexity, uncertainty, or ambivalence about trade in many Americans' minds. Furthermore, the responses to only two of the three closed questions (the two that are logically connected) were strongly related to each other among ANES respondents: the Pearson correlation coefficient between favoring "free trade agreements" and saying that "increasing trade" is "good" is a robust 0.47 , quite high for two attitudinal survey items. The "limit imports" item is negatively (and less strongly) related to the other two: $r=-0.28$ with favoring free trade agreements and $r=-0.32$ with thinking increasing trade is good. This negative relationship is sensible, given that a preference for limiting imports indicates less positivity toward free trade. While the three 
close-ended trade items are related to one another in expected directions, it is not clear that they measure a single unified construct. The weighted Cronbach's $\alpha$ for these three items is a middling .52. Rather, the various ways in which trade attitudes are measured may tap into distinct dimensions of political attitudes.

This interpretation gains plausibility when we check the relationships between openended responses closed-ended responses by the same individuals. It turns out that the two are barely related to each other at all. In order to investigate these relationships, we confined our attention to the 201 respondents who gave trade-related open-ended responses. Using a simple but reasonable heuristic, we coded their open-ended comments as "pro" trade if they were given as a like of Clinton (clearly, to most Americans, a free trader) or if the comments were given as a dislike of Trump (with clear protectionist tendencies). Conversely, comments were coded as "anti" trade if they were given as a dislike of Clinton or a like of Trump. (Only 7 respondents made two comments pointing in opposite directions; they were omitted from this analysis.) We then cross-tabulated these open-ended "pro" and "anti" trade comments with the same individuals' answers to each of the three closed-ended trade questions. The results are displayed in Table 3. 
Table 3

Relationships between Open- and Closed-ended Responses

\begin{tabular}{r|ccc}
\hline \multicolumn{3}{c}{ Open-Ended Trade Attitude } \\
\hline & & Pro & Anti \\
Limit & No & 0.245 & 0.755 \\
Imports & Yes & 0.231 & 0.769 \\
\hline Column N & & 36 & 98 \\
\hline
\end{tabular}

Note: Cells are row proportions calculated with ANES survey weights.

Column Ns are unweighted counts.

Chi-square $\mathrm{p}>.85$; Pearson's $\mathrm{r}=.01(\mathrm{p}>.80) ; \mathrm{N}=134$.

\begin{tabular}{c|rcc}
\hline \multicolumn{3}{c}{} & \multicolumn{2}{c}{ Open-Ended Trade Attitude } \\
\hline & & Pro & Anti \\
& Favor a great deal & 0.242 & 0.758 \\
& Favor moderately & 0.356 & 0.644 \\
Trade & Favor a little & 0.445 & 0.555 \\
Agreements & Neither favor nor oppose & 0.225 & 0.775 \\
& Oppose a little & 0.067 & 0.933 \\
& Oppose moderately & 0.069 & 0.931 \\
& Oppose a great deal & 0.191 & 0.809 \\
\hline Column N & & 42 & 127 \\
\hline
\end{tabular}

Note: Cells are row proportions calculated with ANES survey weights.

Column Ns are unweighted counts.

Chi-square $\mathrm{p}>.20$; Pearson's $\mathrm{r}=-.15(\mathrm{p}<.05) ; \mathrm{N}=170$.

\begin{tabular}{l|lcc}
\hline \multicolumn{2}{c}{} & Open-Ended Trade Attitude \\
\hline & & Pro & Anti \\
Increasing Trade & Good & 0.253 & 0.747 \\
& Neither good nor bad & 0.228 & 0.772 \\
& Bad & 0.164 & 0.836 \\
\hline Column N & & 39 & 129 \\
\hline
\end{tabular}

Note: Cells are row proportions calculated with ANES survey weights.

Column Ns are unweighted counts.

Chi-square $\mathrm{p}>.55$; Pearson's $\mathrm{r}=-.09(\mathrm{p}>.20) ; \mathrm{N}=168$. 
As the table makes clear, the open- and closed-ended trade measures were barely related to each other. Only favoring or opposing new trade agreements may have been related to open-ended pro- and anti-trade sentiments with statistical significance - and that significance depends upon the assumptions of interval-level measurement and linearity that are inherent in statistical tests for Pearson correlation coefficients. (The Chi-square was clearly non-significant). That relationship was negative $(\mathrm{r}=-.15, \mathrm{p}<.05)$, reflecting the fact that favoring trade agreements would correlate negatively with anti-trade sentiments. The other two relationships were quite small and altogether without statistical significance (Chi squares >.55 and >.85). To us, this rather surprising finding casts further doubt upon the meaning of responses to the simple closed trade questions. Clearly, many who voiced agreement with the generalized pro-trade sentiments embodied in the ANES closed questions nonetheless spontaneously expressed qualms in response to the open-ended questions - qualms that often went outside the boundaries of the closed questions, often focusing on jobs, wages, factory closings, and the like.

We believe that these divergently expressed sentiments reflect real ambivalence in citizens' minds. We suspect that many people profess to believe in free trade so long as it is also "fair trade," or consider "free trade" in the abstract (but not necessarily concrete examples of it) to signify a Good Thing. They may silently qualify their protrade responses to forced-choice, closed-ended questions in ways not captured by the response alternatives - for example, wanting various types of relief from (or compensation for) import pressures. Some evidence indicates that skepticism about imports was an important ingredient in decisions by many whites who had voted for Obama in 2012 to switch and vote for Trump in the 2016 general election, as well as in decisions by many Republican primary voters to pick Trump (Ferguson et al. 2020). If so, this factor may have been missed by many observers who were confident of a Clinton victory. And their misplaced confidence may have resulted in part from reliance on a small set of trade-related closed-ended survey questions.

\section{Conclusion}

Since the time of the New Deal, the mainstream of corporate America, political leaders, the mass media, and conventional economics have generally treated free trade as the 
incarnation of sound public policy and right thinking (Stiglitz 2004.) The heavy weight of the official mind on this topic appears to have percolated down to many ordinary citizens, but not with complete success. Simple closed-ended survey questions about "trade" or "free trade" generally yield strong majority support for trade. A focus on data from a few such questions that ignore qualifications and complexities in opinions has contributed to a misleading conventional wisdom that large majorities of Americans support free trade with little or no qualifications. It probably also contributed to an underestimation of Donald Trump's chances of winning the presidency in 2016.

Our examination of a broad range of closed-question data, together with responses to the ANES open-ended questions, reveals a picture with more complexity, ambivalence, and negativity. In particular, the open-ended data indicate that the relatively highsalience or high-intensity citizens who spontaneously mentioned trade-related matters expressed great deal of negativity, by a ratio of about 3 to 1 over their positive comments. This is much more negativity than is revealed by the most popular closed questions. It is largely rooted in concrete concerns about jobs, wages, factory closings, and the like.

Moreover, the closed ANES questions do not hang together well. The "limit imports" item is only weakly and negatively related to the two that refer to "trade agreements" or amounts of "trade" (which of course includes exports as well as imports.) That finding - along with the finding that individuals' open-ended trade-related comments have little or no statistical relationship at all with their closed-question responses - suggest that these simple closed questions may largely represent facile repetition of the conventional wisdom of the day, rather than concrete and seriously held attitudes.

Taken together, our results suggest a point that goes beyond the specifics of international trade. On any issue of public policy, a small set of closed questions - no matter how well designed or selected - is unlikely to reveal the full shape of people's attitudes about that issue. Such closed questions may altogether miss concerns that are central in citizens' minds but not on the minds of the pollsters. This can become a serious concern for public discourse and democratic policy making if most or all pollsters in the country tend to ask 
closed questions with similar lacunae or biases. Open-ended survey data can often help, either as a supplement or as a corrective. 


\section{References}

Autor David, David Dorn, Gordon Hanson, and Kaveh Majlesi. "Importing Political Polarization? The Electoral Consequences of Rising Trade Exposure. MIT Working Paper. Cambridge, Mass.: Massachusetts Institute of Technology, 2016.

Autor David, David Dorn, Gordon Hanson, and Kaveh Majlesi. "A Note on the Effect of Rising Trade Exposure on the 2016 Election." Cambridge, Mass.: Massachusetts Institute of Technology, 2017.

Backstrom, Charles Herbert, and Gerald Hursh-César. Survey Research. 2nd ed. New York : Macmillan ; London : Collier Macmillan, 1981.

https://trove.nla.gov.au/version/29357259.

Berent, Matthew K., Jon A. Krosnick, and Arthur Lupia. "Coding Open-Ended Answers to Questions Measuring Reasons to Vote For or Against Candidates from the 2008 ANES Time Series Interviews," February 2015. https://electionstudies.org/2008-open-endedcoding-project/.

Bouton, Marshall M. Global Views 2004: American Public Opinion and Foreign Policy. Chicago: Chicago Council on Foreign Relations, ed. 2004.

Bouton, Marshall M. Anxious Americans Seek a New Direction in United States Foreign Policy. Chicago: Chicago Council on Global Affairs, ed. 2008.

Bouton, Marshall M. Constrained Internationalism: Adapting to New Realities. Chicago: Chicago Council on Global Affairs, ed. 2010.

Bouton, Marshall M., and Benjamin I. Page. Worldviews 2002: American Public Opinion and Foreign Policy. Chicago: Chicago Council on Foreign Relations, eds. 2002.

Case, Anne, and Angus Deaton. "Mortality and Morbidity in the Twenty-First Century." Washington, D.C.: Brookings Institution, 2017.

Campbell, Angus, Philip E. Converse, Warren E. Miller, and Donald E. Stokes. Elections and the Political Order. Wiley, 1966.

- The American Voter. Chicago Ill.: University of Chicago Press, 1980 Abridged ed. Orig. pub. 1960.

Craig, Stephen C. "The Decline of Partisanship in the United States: A Reexamination of the Neutrality Hypothesis." Political Behavior 7, no. 1 (1985): 57-78.

Cramer, Katherine J. The Politics of Resentment: Rural Consciousness and the Rise of Scott Walker. Chicago, IL: University of Chicago Press.

Economist. "Briefing: Barack Obama, The Way Ahead.” Oct. 8, 2016.

https://www.economist.com/briefing/2016/10/08/the-way-ahead

Ferguson, Thomas, Benjamin I. Page, Jacob Rothschild, Arturo Chang, and Jie Chen. "The Roots of Right-Wing Populism: Donald Trump in 2016." International Journal of 
Political Economy 49, no. 2 (2020): 102-123;

https://doi.org/10.1080/08911916.2020.1778861

Ferguson, Thomas. "The Right Consensus?: Holsti and Rosenau's New Foreign Policy Belief Surveys. International Studies Quarterly 30, No. 4 (December, 1986): 411-23; https://doi.org/10.2307/2600642

Friedman, Thomas L. The World is Flat: A Brief History of the Twenty-first Century. 2007. Updated and expanded ed. New York: Farrar, Straus and Giroux, 2007.

Geer, John G. “Do Open-Ended Methods Measure 'Salient' Issues?” Public Opinion Quarterly 55, no. 3 (January 1, 1991): 360-70. https://doi.org/10.1086/269268.

—. "What Do Open-Ended Questions Measure?" Public Opinion Quarterly 52, no. 3 (January 1, 1988): 365-67. https://doi.org/10.1086/269113.

Irwin, Douglas A. Free Trade Under Fire. $4^{\text {th }}$. ed. Princeton: Princeton University Press. Kelley, Stanley. Interpreting Elections. Princeton University Press, 1983.

Kessel, John H. The Goldwater Coalition: Republican Strategies in 1964. First Edition. The Bobbs-Merrill Company, Inc., 1968.

Knight, Kathleen. "Ideology in the 1980 Election: Ideological Sophistication Does Matter." The Journal of Politics 47, no. 3 (August 1, 1985): 828-53. https://doi.org/10.2307/2131213.

Krugman, Paul R., Maurice Obstfeld, and Marc J. Meliz. International Economics: Theory and Policy. 10 ${ }^{\text {th }}$. ed. New York: Pearson, 2015.

Lupia, Arthur. "How to Improve Coding for Open-Ended Survey Data: Lessons from the ANES." In The Palgrave Handbook of Survey Research, edited by David L. Vannette and Jon A. Krosnick, 1st ed. 2018 edition. New York, NY: Palgrave Macmillan, 2017.

Monnat, Shannon, and David Brown. "Deaths of Despair and Support for Trump in the 2016 Presidential Election.” Journal of Rural Studies 55 (October): 227-36, 2017.

Page, Benjamin I., and Robert Y. Shapiro. The Rational Public: Fifty Years of Trends in Americans' Policy Preferences. Chicago: University of Chicago Press, 1992.

Pew Research Center. "Free Trade Agreements Seen as Good for U.S., But Concerns Persist." May 27, 2015. https://www.people-press.org/2015/05/27/free-trade-agreementsseen-as-good-for-u-s-but-concerns-persist/

Ramage, Daniel, David Hall, Ramesh Nallapati, and Christopher D. Manning. "Labeled LDA: A Supervised Topic Model for Credit Attribution in Multi-Labeled Corpora." Proceedings of the 2009 Conference on Empirical Methods in Natural Language Processing, 2009, 248-56.

RePass, David E. "Issue Salience and Party Choice." The American Political Science Review 65, no. 2 (1971): 389-400. https://doi.org/10.2307/1954456.

Ricardo, David. The Principles of Political Economy and Taxation. Homewood, Illinois: Irwin, 1963 [orig. pub. 1817].

Rielly John E. American Public Opinion and U.S. Foreign Policy 1975. Chicago: 
Chicago Council on Foreign Relations. Similarly titled volumes published in 1975, 1979, 1983, 1987, 1991, 1995, and 1999, ed. 1975.

Roberts, Margaret E., Brandon M. Stewart, Dustin Tingley, Christopher Lucas, Jetson Leder-Luis, Shana Kushner Gadarian, Bethany Albertson, and David G. Rand. "Structural Topic Models for Open-Ended Survey Responses." American Journal of Political Science 58, no. 4 (2014): 1064-82. https://doi.org/10.1111/ajps.12103.

Rodrik, Dani. Straight Talk on Trade. Princeton: Princeton University Press, 2018.

Rothschild, Jacob E., Adam J. Howat, Richard M. Shafranek, and Ethan C. Busby. "Pigeonholing Partisans: Stereotypes of Party Supporters and Partisan Polarization." Political Behavior, March 28, 2018. https://doi.org/10.1007/s11109-018-9457-5.

Saad, Lydia. “Americans' Views on Trade in the Trump Era.” Gallup, October 25, 2019. https://news.gallup.com/opinion/gallup/267770/americans-views-trade-trump-era.aspx

Samuelson, Paul. "International Trade and the Equalisation of Factor Prices." Economic Journal 58: 163-184, 1948.

Samuelson, Paul. "International Factor Price Equalisation Once Again.” Economic Journal 59: 181-196, 1949.

Samuelson, Paul. “Ohlin Was Right.” Swedish Journal of Economics 73 (1971), 365384, 1971.

Schuman, Howard, Jacob Ludwig, and Jon A. Krosnick. "The Perceived Threat of Nuclear War, Salience, and Open Questions." Public Opinion Quarterly 50, no. 4 (1986): 519-36. https://doi.org/10.1086/269001.

Schuman, Howard W., and Stanley Presser. Questions and Answers in Attitude Surveys: Experiments on Question Form, Wording, and Context. Thousand Oaks, CA: SAGE Publications, Inc, 1996 [orig. pub. 1981].

Schmidt, Katharina, Tobias Gummer and Joss Rossmann, "Effects of Respondent and Survey Characteristics on the Response Quality of an Open-Ended Attitude Question in Web Surveys. Methods, Data, Analyses 14 (1) 2020, pp. 3-34.

Scott, Robert E. "Heading South: U.S.-Mexico Trade and Job Displacement After NAFTA.” Economic Policy Institute, May 3, 2011. https://www.epi.org/publication/heading_south_u-smexico_trade_and_job_displacement_after_nafta1/

Scott, Robert E., and Zane Mokhiber. "Growing China Trade Deficit Cost 3.7 Million American Jobs Between 2001 and 2018." Economic Policy Institute, January 30, 2020. https://www.epi.org/publication/growing-china-trade-deficits-costs-us-jobs/

Sides, John, Michael Tesler, and Lynn Vavreck. 2018. Identity Crisis: The 2016

Presidential Campaign and the Battle for the Meaning of America. Princeton: Princeton University Press.

Smeltz, Dina, Ivo Daalder, Karl Friedhoff, and Craig Kafura. America in the Age of Uncertainty: American Public Opinion and Foreign Policy. Chicago: Chicago Council on Global Affairs, 2016. 
Smeltz, Dina, Ivo Daalder, Karl Friedhoff, Craig Kafura, and Brendan Helm. Rejecting Retreat: Americans Support U.S. Engagement in Global Affairs. Chicago: Chicago Council on Global Affairs, 2019.

Smith, Adam. An Inquiry into the Nature and Causes of the Wealth of Nations. Ed. Edwin Cannan. Chicago: University of Chicago Press, 1976 [orig. pub. 1776].

Stanga, John E., and James F. Sheffield. "The Myth of Zero Partisanship: Attitudes toward American Political Parties, 1964-84." American Journal of Political Science 31, no. 4 (1987): 829-55. https://doi.org/10.2307/2111226.

Stiglitz, Joseph. 2004. The Roaring Nineties. New York: W.W. Norton.

Stokes, Donald E. "Some Dynamic Elements of Contests for the Presidency." American Political Science Review 60, no. 1 (March 1966): 19-28.

https://doi.org/10.2307/1953803.

Stokes, Donald E., Angus Campbell, and Warren E. Miller. "Components of Electoral Decision.” The American Political Science Review 52, no. 2 (1958): 367-87. https://doi.org/10.2307/1952322.

Stolper, Wolfgang, and Paul Samuelson. "Protection and Real Wages." Review of Economic Studies 9 (November): 58-73, 1941.

Taylor, Lance, and Oslem Omer. "Race to the Bottom: Low Productivity, Market Power, and Lagging Wages." Institute for New Economic Thinking Working Paper No. 80., 2018. https://www.ineteconomics.org/research/research-papers/race-to-the-bottom-lowproductivity-market-power-and-lagging-wages

Vannette, David L., and Jon A. Krosnick, eds. The Palgrave Handbook of Survey Research. 1st ed. 2018 edition. New York, NY: Palgrave Macmillan, 2017.

Wattenberg, Martin. Decline of American Political Parties, 1952-84. 2nd edition. Cambridge, Mass: Harvard University Press, 1986.

Wattenberg, Martin P. “The Decline of Party Mobilization.” In Parties Without Partisans: Political Change in Advanced Industrial Democracies, edited by Martin P. Wattenberg and Russel J. Dalton, 64-76. Oxford University Press, 2002. http://www.oxfordscholarship.com/view/10.1093/0199253099.001.0001/acprof9780199253098-chapter-4.

Zaller, John, and Stanley Feldman. "A Simple Theory of the Survey Response: Answering Questions versus Revealing Preferences." American Journal of Political Science 36, no. 3 (1992): 579-616. https://doi.org/10.2307/2111583. 


\section{Appendix}

Examples of Raw and Chunked Open-ended Trump "Likes" and "Dislikes" Responses from the 2016 American National Election Study (ANES)

\begin{tabular}{|c|l|}
\hline $\begin{array}{l}\text { Respondent } \\
\text { Number }\end{array}$ & \multicolumn{1}{c|}{ Trump "Likes" Raw Text } \\
\hline 300121 & $\begin{array}{l}\text { That I want to vote for him because he wants to put a holt on letting imigrates in until they } \\
\text { are fulley veted }\end{array}$ \\
\hline 300098 & bussimness man built mil tary up take care of vet medical ins/ \\
\hline 300053 & he is advocating chang which is needed in many areas// \\
\hline 300106 & $\begin{array}{l}\text { succeed or fail he is a business tycoon he knows how to get things done he sys excctly what } \\
\text { he means }\end{array}$ \\
\hline 300376 & $\begin{array}{l}\text { hes not an esatblishment candidate// only reason in a million years id consider voting for } \\
\text { him//he walks to his beat//he doesnnt answer people// }\end{array}$ \\
\hline
\end{tabular}

\section{Trump "Likes" Chunked and Spell-Corrected Text}

\begin{tabular}{|c|c|c|c|c|}
\hline Chunk 1 & Chunk 2 & Chunk 3 & $\begin{array}{l}\text { Chunk } 4 \\
\end{array}$ & Total \\
\hline $\begin{array}{l}\text { That I want to vote for him } \\
\text { because he wants to put a [hold] } \\
\text { on letting [in immigrants] until } \\
\text { they are [fully] [vetted.] }\end{array}$ & & & & 1 \\
\hline [Business] man & Build[military] up & $\begin{array}{l}\text { Take care of [veteran] } \\
\text { medical [insurance] }\end{array}$ & & 3 \\
\hline $\begin{array}{l}\text { He is advocating [change] which } \\
\text { is needed in many areas }\end{array}$ & $\begin{array}{l}\text { which is needed } \\
\text { in many areas }\end{array}$ & & & 2 \\
\hline $\begin{array}{l}\text { Succeed or fail he is a business } \\
\text { tycoon }\end{array}$ & $\begin{array}{l}\text { He knows how to } \\
\text { get things done }\end{array}$ & $\begin{array}{l}\text { He [says] [exactly] } \\
\text { what he means }\end{array}$ & & 3 \\
\hline $\begin{array}{l}\text { He's not an [establishment] } \\
\text { candidate// }\end{array}$ & $\begin{array}{l}\text { Only reason in a } \\
\text { million years I'd } \\
\text { consider voting } \\
\text { for him// }\end{array}$ & he walks to his beat// & $\begin{array}{l}\text { He } \\
\text { [doesn't] } \\
\text { answer } \\
\text { [to] } \\
\text { people// }\end{array}$ & 4 \\
\hline
\end{tabular}




\begin{tabular}{|c|l|}
\hline Respondent Number & \multicolumn{1}{|c|}{ "Trump Dislikes" Raw Text } \\
\hline 300007 & $\begin{array}{l}\text { inexoerience in politics, and I dont know how a person has always had his way will } \\
\text { deal with congress, what will he fire them if they vote against him// }\end{array}$ \\
\hline 300023 & $\begin{array}{l}\text { view on immiration, hard line towards Muslims in general, lack of experience in office, } \\
\text { being a frea monger// }\end{array}$ \\
\hline 300042 & $\begin{array}{l}\text { I don't think he knows enough about national defence and i don't think e's very } \\
\text { educated in the military }\end{array}$ \\
\hline 300109 & $\begin{array}{l}\text { he offends the latin community,he has no respect for prople especially women, he } \\
\text { doesnt care about people in general, its about business with, very disrespectful// }\end{array}$ \\
\hline 300113 & $\begin{array}{l}\text { loose canon some of the stuff I've seen him say and do makes me not want to vote for } \\
\text { him//he told him to get the guy and beat him down and he would pay for the } \\
\text { lawyer//his hair }\end{array}$ \\
\hline
\end{tabular}

\section{Trump "Dislikes" Chunked and Spell-Corrected Text}

\begin{tabular}{|c|c|c|c|c|c|c|}
\hline Chunk 1 & Chunk 2 & Chunk 3 & Chunk 4 & Chunk 5 & Chunk 6 & Total \\
\hline $\begin{array}{l}\text { [inexperience } \\
\text { in politics] }\end{array}$ & $\begin{array}{l}\text { And I don't } \\
\text { know how a } \\
\text { person had } \\
\text { always had his } \\
\text { way will deal } \\
\text { with Congress }\end{array}$ & $\begin{array}{l}\text { [What,] will } \\
\text { he fire them if } \\
\text { they vote } \\
\text { against him// }\end{array}$ & & & & 3 \\
\hline $\begin{array}{l}\text { View on } \\
\text { [immigration] }\end{array}$ & $\begin{array}{l}\text { Hard line } \\
\text { towards } \\
\text { Muslims in } \\
\text { general }\end{array}$ & $\begin{array}{l}\text { Lack of } \\
\text { experience in } \\
\text { office }\end{array}$ & $\begin{array}{l}\text { Being a } \\
{[\text { fear }} \\
\text { monger]// }\end{array}$ & & & 4 \\
\hline $\begin{array}{l}\text { I don't think } \\
\text { he knows } \\
\text { enough about } \\
\text { national } \\
\text { [defense] }\end{array}$ & $\begin{array}{l}\text { And I don't } \\
\text { think [he's] } \\
\text { very educated } \\
\text { in the military }\end{array}$ & & & & & 2 \\
\hline $\begin{array}{l}\text { He offends } \\
\text { the Latin } \\
\text { community }\end{array}$ & $\begin{array}{l}\text { He has no } \\
\text { respect for } \\
\text { [people] }\end{array}$ & $\begin{array}{l}\text { Especially } \\
\text { women }\end{array}$ & $\begin{array}{l}\text { He doesn't } \\
\text { care about } \\
\text { people in } \\
\text { general }\end{array}$ & $\begin{array}{l}\text { It's about } \\
\text { business } \\
\text { with }\end{array}$ & $\begin{array}{l}\text { Very } \\
\text { disrespectful }\end{array}$ & 6 \\
\hline $\begin{array}{l}\text { Loose } \\
\text { [cannon] }\end{array}$ & $\begin{array}{l}\text { Some of the } \\
\text { stuff I've seen } \\
\text { him say and } \\
\text { do makes me } \\
\text { not want to } \\
\text { vote for him// }\end{array}$ & $\begin{array}{l}\text { He told him } \\
\text { to get the guy } \\
\text { and beat him } \\
\text { down and he } \\
\text { would pay for } \\
\text { the lawyer }\end{array}$ & His hair & & & 4 \\
\hline
\end{tabular}

